\title{
Heritage in Translation: "A Dagur Story" as Historical Fiction and Sample Text for Learning Manchu - Part Two
}

\author{
MONICA KIN-IAN CHANG \\ Independent Scholar, formerly affiliated with the University of Macau
}

GARY CHI-HUNG LUK

University of London

EUGENE SHUN-YUNG TAM

Hong Kong Polytechnic University

Volume 14, 2016-2017

This article follows the one in Volume 13 of this journal. It further explains the challenges of translating into English and Chinese A Dagur Story, a Manchu-language historical fiction about the Dagur tribe's activities in the anti-Russian campaigns in Qing territory during the seventeenth century. It comprises the Romanized transliteration, Chinese translation, and English translation of three excerpts of the novel selected by the authors, and also the authors' commentaries on the trilingual translation. The major issues addressed in the commentaries include the Chinese and English translations of proper nouns, the semantic and grammatical issues regarding the Manchu-Chinese and Manchu-English translations, and the discrepancies between the Chinese and English translated texts as well as the rationales behind the difference.

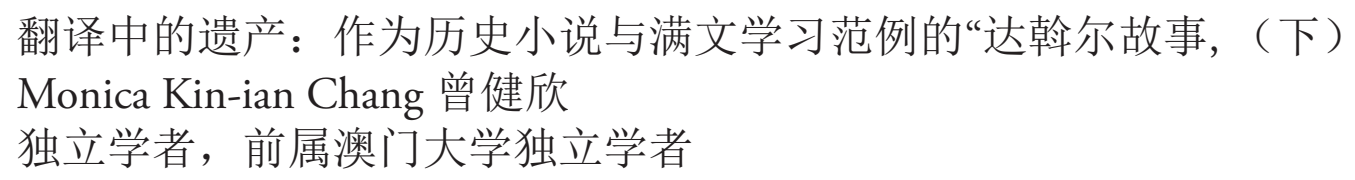

Eugene Shun-yung Tam 谭淳翁

香港理工大学 
本文是本期刊第十三期论文的下半部, 进一步探讨翻译达斡尔故事时所遇到 的挑战。（达斡尔故事是一部满文历史小说, 讲述十七世纪达斡尔人如何抵 抗俄罗斯人入侵清领土。）本文包括三段摘录段落的罗马化音译，中英文翻 译，以及作者对三语翻译的意见。意见的部分主要涉及专有名词的翻译， 关于满中, 满英翻译的语意和文法问题, 以及中英文译本的相异之处和背后 的原因。

翻譯中的遺產：作為歷史小說與滿文學習範例的“達斡爾故事”（下）

Monica Kin-ian Chang 曾健欣

獨立學者，前屬澳門大學

Gary Chi-hung Luk 陸志鴻

倫敦大學

Eugene Shun-yung Tam 譚淳翁

香港理工大學

本文是本期刊第十三期論文的下半部，進一步探討翻譯達斡爾故事時所遇到 的挑戰。（達斡爾故事是一部滿文歷史小說, 講述十七世紀達斡爾人如何抵 抗俄羅斯人入侵清領土。）本文包括三段摘錄段落的羅馬化音譯, 中英文翻 譯, 以及作者對三語翻譯的意見。意見的部分主要涉及專有名詞的翻譯, 關 於滿中、滿英翻譯的語意和文法問題, 以及中英文譯本的相異之處和背後的 原因。

The excerpts representing the work of three members participating in the translation of $A$ Dagur Story (Dahu'er gushi 達呼爾故事) reflect two essential characteristics of the project as a whole: translators work both independently and collaboratively, and contextualizing the content is as important as achieving accurate linguistic conversion. ${ }^{1}$ One of this article's authors has worked entirely alone, and the other two authors are primarily responsible for separate sections but have worked together on some aspects of translation as well. This article is composed of three sections, each reflecting its author's disciplinary background. The first and third sections are based on the authors' expertise in modern Chinese history, whereas the second section concentrates on linguistic analysis. Each commentary exemplifies how the translation process is highly individualized yet fulfils the common goal of clarifying some meanings within the original text, which is a work of fiction.

1. Dahu'er gushi is a Manchu hand-written manuscript written by Kūkejintai (Hugejintai 胡格金台) and published in Taipei by the Wenshizhe Press (Wenshizhe chubanshe 文史哲出版社) in 1977. 
Similar to the first installment of the translation featured in Volume 13 of this journal, each of the excerpts below are divided into three sections: Romanized transliteration, Chinese translation, and English translation. Following the order of chapters in the novel, the excerpts to be featured in this article are from Chapters 11, 12, and 14. They are respectively translated by Monica Kin-ian Chang, Eugene Shun-yung Tam, and Gary Chi-hung Luk.

\section{Chapter 11, pages 78 and 79}

\section{Monica Chang Kin-ian}

\section{Transliteration (with proper nouns underlined)}

Juwan emuci; ehe arbun de hafirabume eme jui ukame yabuha..

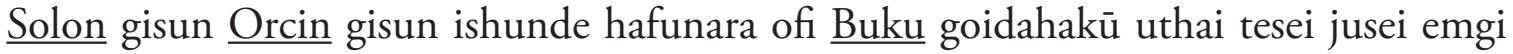
sain gucu oho .. A Lun goidame Orcin i bade tehe of tulergi baita hacin be dembei sarkū ofi . uthai Aisin Loho sakda de Oros de daljilaha baita be fonjire de . Aisin sakda hendume ; Oros niyalma Bai Li de afahaci ebsi utala aniya udu ambarame necinjihekū

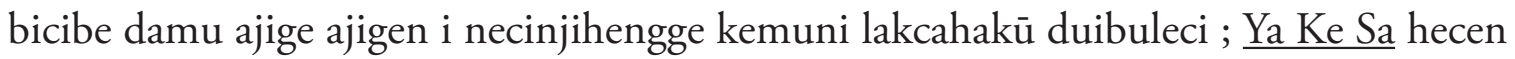
be ejeleheci ebsi julergi baru Ergune bira i jergi babe necime emu babe ejelehe dari gemu hecen sahame geli Oros gisun i ejelehe babe gebuleme ceni ba na obure mujin . nede $\mathrm{Ni} \mathrm{Bu} \mathrm{Cu}$ i babe fulehe obume ambarame tulergi baru necime bimbi .. $\mathrm{Ni} \mathrm{Bu}$ $\underline{\mathrm{Cu}}$ oci Ai Hoi i wargi amargi i juwe minggan ba funceme Ya Ke Sa hecen i adali gemu Sahaliyan ulai bitume bi . muke olhon jugūn gemu ildungga . ere juwe ba i harangga ba gemu Oros de ejelebuhe .. A Lun eme jui Aisin sakda i boo de emu dobori dedume jai inenggi uthai erde jurame Orcin niyalmai fargara ci geleme inenggi dobori gemu moo

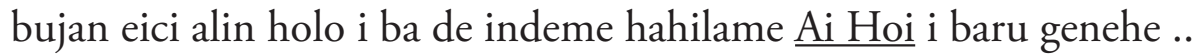

\section{Chinese}

第十一章: 母子慌忙逃脫

索倫話和鄂倫春話相通, 不一會兒布庫就和他們的孩子們打成一片。阿綸在 鄂倫春住太久, 都不知道外頭是怎樣的情況了。所以問老人愛新羅和有關俄 羅斯的事情。愛新老人答道：「俄羅斯人進入百里至今, 雖然很多年都沒有 重大侵略, 但規模小的侵犯可沒中斷過。他們佔據雅克薩城、往南走到額爾 古納河各個地方一帶入侵、在每個地方都築起城牆, 並給各地方起俄羅斯文 名字, 想將所有城都據為己有。現在正入侵尼布楚一帶。尼布楚位處璦琿西 
北二千多里, 和雅吉薩城一樣接壤黑龍江, 海、陸路都方便。這兩地方都被 俄羅斯人佔據了。」阿綸母子在愛新老人家住了晚，明早上早早出發，為了 避開鄂倫春人的追捕, 日夜都在山谷留宿, 往瑗琿的方向走去。

\section{English}

\section{Chapter 11: Mother and Son's Escape}

As the languages of the Solon and Orochen people are mutually intelligible, Buku quickly got along with their children. Arun had been living with the Orochen for so long that she did not know what was happening outside. She thus asked the old man Aisin Loho about the Russians and he answered, "The Russians, for many years, have not started another major invasion after entering Baili. However, their slight encroachments [upon Qing territory] have never ceased. They occupied the city of Yaksa, ${ }^{2}$ moved southwards, encroaching on various points on the Argun River, built a wall in each of those places, and by giving these places Russian-language names, have tried to make the cities their own. ${ }^{3}$ They are now principally invading the regions around and toward Nibcu. ${ }^{4} \mathrm{Nibcu}$ is over 2,000 li northwest of Aihun and borders the Amur River like the city of Yaksa. It is convenient to access both by sea and land. The area belonging to these two places are also occupied by the Russians." Arun and her son spent a night at the old man Aisin's place. They left in the early morning. Fearing the pursuit of the Orochen people, they rested in the mountain valleys day and night and rushed toward Aihun.

\section{Commentary}

Translation of this section, again, does not escape the problems previously encountered in the parts translated in the first installment. The problem of translating proper nouns, especially personal names, still poses challenges to the translators. In this excerpt, the name of the old man is translated according to the Romanized form, Aisin Loho. Translating the family name poses no problem as "Aisin" has a standard translation 「愛 新」, but the translation of the given name into Chinese has to be decided by the translators. 「羅和」 is chosen because it sounds similar to the Manchu phonemes and it looks like a name for men as well. In relation to translating personal names, translators must consider the masculinity and femininity of the Chinese. For example, one may prefer to render the name of the female protagonist, Arun (Romanized form: A Lun),

2. The term "city" here is more properly understood as a fortress with a wall that enclosed space for residence and communal activities.

3. The Ergune River (Ch. E'erguna he額爾古納河, Ru. Argún’ reka Аргу́нь река) is also known as the Argun River in English.

4. Nibcu is conventionally known in English by its Russian name, Nerchinsk. 
as「阿倫」, since the Chinese character 「倫」 is commonly used for 「綸」with the radical 「糸」 which is conventionally used in female names.

Translating place names is also problematic for translators. This excerpt contains several place names that are important to the reader's understanding. Correctly translating those names to assist readers' understanding thus creates another challenge for translators. For example, the use of "Yaksa" is not chosen without attention. The reason is that this place belonged alternately to China and Russia. ${ }^{5}$ Yaksa is today's Albazin in Russia. This name is not as controversial as that of the Diaoyu Islands 釣魚臺 (known in Japanese as the Senkaku Islands 尖閣列島), for which identification by either the Chinese or Japanese names suggests which government should rightfully claim it. However, the translator still has to choose a translation that is clear to the modern reader without justifying Qing control of Yaksa at the time while also fitting the story's context. Given these considerations, "Yaksa" is the best choice because, as mentioned above, it follows the Manchu phonemes and matches the political authority of that time.

Chapter 12, pages 80 and 81

\section{Eugene Shun-yung Tam}

\section{Transliteration (proper nouns underlined)}

Juwan juweci .. fe be gūnime ice be ashūha ..

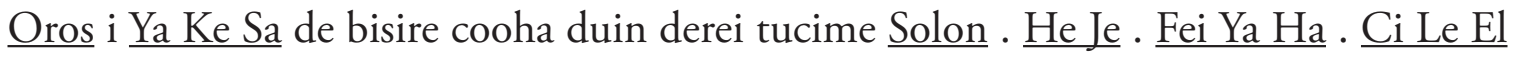
. Dahor jergi geren bade kemuni tabcilame ${ }^{6}$ yabure de Cing gurun janggin Ping Cun de hese wasimbufi duin minggan cooha fideme afabufi Oros cooha be dailabume unggihe .. ere amba coohai meyen i dolo Batu i suwayan tui kūwaran ${ }^{7}$ i cooha inu E Su

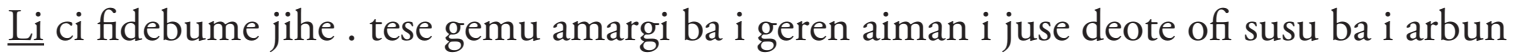
dursun be hafu ureshūn de Batu i jorime afabure be dahame bata be hetureme afara eici fargame $^{8}$ wara de gemu etere nashūn be ufararakū ..

damu ere mudan i dain de $\underline{\text { Batu }}$ i bethe feye bahafi Batu uthai ini coohai tušan be Ci Na ci daiselabume ini beye oktosi be kadalara yamun de dosime feye be dasabuha .. tere erinde coohai oktosi yamun udu dembei sain akū bicibe damu Batu oci emu tung ling jergi amba coohai hafan ofi . eiten baitalara okto gemu muterei teile sain ningge

5. Yaksa was originally established by the Dagur people. The Russians invaded the city in 1651 and established the fort of Albazin in its place. The Albazin troops were defeated by the Qing army in 1686, and under the Treaty of Nerchinsk this area henceforth belonged to China. In 1860, this area was ceded to the Russians under the Convention of Peking and since then has been part of the Russian Empire, the Soviet Union, and, since 1990, the Russian Federation.

6. This word looks like "dacilame."

7. This word looks like "kuwaran."

8. This word looks like "wargame." 
be baitalame geli Batu i jalin nimekungge niyalma be eršere emu asigan hojo siyoo jiyei be tomilaha .. ere siyoo jiyei i gebu oci 奥a . He Je aiman i niyalma . ineku facuhūn ci jailame tule tucinjime hergime yabure de banjire de hafirabufi tuttu ubade jime nimekungge niyalma be eršere baita be alihabi ..

\section{Chinese}

第十二章: 拒新戀舊 9

在雅克薩的俄軍經常四出掠奪索倫、赫哲、費雅哈、10 奇勒爾、達斡爾等 很多地方時, 清國章京平春 ${ }^{11}$ 奏請聖旨調動四千大軍征討俄軍。這大軍裏面 巴圖的黃旗護軍營的士兵也從額蘇哩調過來了。由於他們全部都是來自北面 各部族的子弟, 因為熟識故鄉地勢以及由巴圖帶領進擊, 而截擊敵人, 並全 部追殺, 得勝之機不可失。

但這次戰役中, 巴圖的腿受傷了。巴圖立即把他的軍務交由奇納暫代並 進入太醫院醫治他的傷處。雖然此時的軍醫院非常不好, 但是因為巴圖是一 統領級別的大武官, 所以在所有可用的藥之中, 只用好藥。而且, 因為巴圖 的關係, 他們指派了一名美麗的女子照顧病人。此女子名為扎沙、赫哲族 人。為避動亂而外逃, 生活艱難, 就此來了這裏做了照顧病人的工作。

\section{English}

\section{Chapter 12: Cherishing the Old, Refusing the New}

While the Russian troops in Yaksa ${ }^{12}$ came out from all directions and frequently plundered the places where the Solon, Heje, Fiyaka, Kiler, and Dagur lived, an imperial edict was sent down to Pingcun, lieutenant general of the Qing empire, to mobilize a force of four thousand troops to wage war against the Russians. Batu's soldiers of the imperial guards brigade were also sent from Esuri to join this group. As they were all native sons of northern tribes, they were familiar with the landforms of their homeland. Also, because Batu directed the attack, this force intercepted the enemy troops (successfully), and in pursuing and killing them, did not miss any opportunities to achieve victory.

But Batu was wounded in his legs in this battle. He immediately turned over his military duties to Cina and entered the Imperial Medical Department to cure

9. This phrase is adopted from the fourteenth fascicle of Lao She 老舍, Lao She wenji 老舍文集 (Beijing: Renmin wenxue chubanshe, 1989), 114-15.

10. This term is also commonly rendered into Chinese as 飛牙喀.

11. The identity of this person is difficult to confirm, and there is also a possibility that this person could have been someone named Pengchun 彭春 or Pengchun 朋春. For a biography of Pengchun, see Qingshi gao 清史稿, ed. Zhao Erxun 趙爾巽 et al. (Beijing, 1928; reprint, Beijing: Zhonghua shuju, 1977), 10136-37.

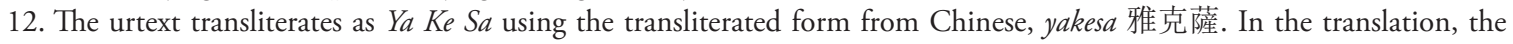
Manchu form is chosen. 
his wound. Although at the time army hospitals were not good, since Batu was an official of the tongling (brigade commander) rank, only the best medicine was used to treat him. Also, because Batu was the patient, a young and beautiful lady was sent to take care of him. This lady was Jasa from the Heje tribe. She left home to run away from chaos. Life was difficult, and so she came here to do the job of taking care of patients.

\section{Commentary}

There has always been a dilemma in the translation of literary texts, especially in more "classical" languages/texts, between aligning with the source language's literary devices and sounding more natural in the target language(s). The rich use of verbs in Manchu texts augmented this challenge, which is, in particular, two-fold. One is to choose suitable verbs in order to make sense in the target language while expressing the meaning carried in the source language. The other is to fit what is heavily converb-linked text in Manchu into the target languages' accepted syntax.

A short excerpt from the text duin minggan cooha fide-me afa-bu-fi Oros cooha be daila-bu-me unggi-he (glossed: four thousand soldier dispatch-COORD fight-CAUSSUBORD Russia(n) soldier ACC make.war.against-CAUS-COORD send.off-PERF) (p. 80 lines 5-6) exemplifies this problem. To stay true to the way of writing in Manchu, the line would be translated as, "four thousand soldiers dispatched to fight and then sent off to wage war against the Russian soldiers." This is rather lengthy and repetitive when represented in English. "Dispatched to fight" and "sent off to wage war against" are indeed synonymous in meaning. It seems that the two languages see verb repetition differently. Manchu texts are enlivened with these verbs and converbs, while replicating this into English would make it redundant. Such difference means that it might be better to translate the text in a way closer to the target language in such cases, and therefore rendering, "mobilizing a troop of four thousand soldiers to wage war against the Russians."

In a similar sentence, phrases expressing events of simultaneous and sequential actions are placed in a string. In the sentence, "ere mudan i dain de Batu $i$ bethe feye bahafi | Batu uthai ini coohai tuśan be $\mathrm{Ci} \mathrm{Na}$ ci daiselabume | ini beye oktosi be kadalara yamun de dosime |feye be dasabuha" (p. 80 line 11-p. 81 line 1; bars added for individual actions and underlining added to represent predicates), four actions are described. The four predicates in the sentence -

1) feye baha-fi "wound obtain-SUBORD";

2) coohai tušan be . . . daiselam-bu-me "army-GEN duty ACC . . make substitute-CAUS-COORD"; 
3) oktosi be kadalara yamun de dosi-me "Imperial Medical Department DAT/ LOC enter-COORD";

4) feye be dasa-bu-ha "wound ACC cure-CAUS-PERF"

- show the logical flow of the sentence. In Manchu, with the aid of converbs and the fact that the syntax allows stringing verbs together, such long sentences are common. The English translation cannot show all coordination and subordination: "But Batu was wounded in his legs in this battle. He immediately turned over his military duties to Cina and entered the Imperial Medical Department to cure his wound." They are instead displayed via phrasal orders. Predicates $2-4$ are coordinated in a string. Predicate 4 shows the purpose in this string, but in English syntax, dasabuha "cure-CAUS-PERF" cannot remain in the perfective but can only be presented as an infinitive.

Translations into English and Chinese sometimes require a different approach. Many compounds in the Manchu text could be translated verbum pro verbo into Chinese. Nimekungge niyalma "sick person" is a patient in English but a bingren 病人 "sick person" in Chinese; heture-me afa-ra "intercept-COORD attack-IMPERF" is intercepted but jieji 截擊 “intercept attack" in Chinese; and fide-bu-me ji-he "transfer-PASSCOORD come-PERF" is translated in English as sent here but simply diaolai le 調來了 "transfer come-PERF" in Chinese. Nimekungge niyalma could be a calque from Chinese because nimekungge itself could be used to refer to a sick person. ${ }^{13}$ On the other hand, translating hetureme afara into English does bring up a problem. To intercept means to "obstruct (someone or something) so as to prevent them from continuing to a destination," ${ }^{14}$ and carries no meaning of attack as does the Chinese expression jieji. However, to translate hetureme afara as to intercept and attack does not sound right either.

Cultural concepts also differentiate translations into English and Chinese. For instance, geren aiman i juse deote "all tribe GEN child.PL younger.brother.PL" (p. 80 line 8 ) is expressed differently in the two target languages. The phrase indeed refers to "the males of all tribes." In Manchu, juse deote refers to "children and younger brothers," while the Chinese equivalent zidi 子弟 "son younger.brother" denotes the same. To render the same concept in English, however, would result in the the sons of all tribes, following Latin traditions fili-i Israël "son-GEN Israel."15

13. "One who is ill" in Jerry Norman, ed., A Concise Manchu-English Lexicon (Seattle: University of Washington Press, 1978), 213; and "der, die, das Kranker" in Erich Hauer and Oliver Cloff, eds., Handwörterbuch der Mandschusprache (Wiesbaden: Harrassowitz, 2007), 368.

14. See Oxford Dictionary of English, "intercept".

15. See Biblia Vulgata, 1 Samuel 17:2. 
Chapter 14, pages 93 and 94

Gary Chi-hung Luk

\section{Transliteration (proper nouns underlined)}

Juwan duici .. bata be eteme šolo baime eme be fujurulaha ..

onggolo gung Ping Cun Ya Ke Sa i bade Oros be gidaha manggi Ya Ke Sa hecen be efulefi Oros niyalma de dahūme hecen sahaci ojorakū seme fafulame uthai cooha be

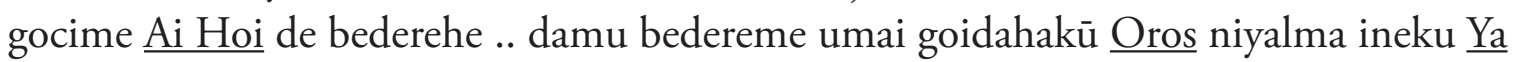
$\underline{\mathrm{Ke}} \mathrm{Sa}$ de hecen sahahangge neneheci beki oho . geli tesei geren irgen be isabufi tarire adularangge nenehe i adali . ereci dabame Solon jergi babe tabcilarangge elei fulu oho ..

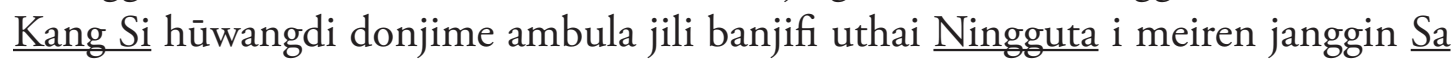
$\underline{\mathrm{Bu}} \mathrm{Su}$ de hese wasimbume siliha cooha be fidefi $\underline{\mathrm{Oros}}$ be dailabuha .. $\underline{\mathrm{Sa} \mathrm{Bu} \mathrm{Su}}$ furdan i dergi dehe jakūn gūsai geren jugūn i cooha. Mukden Ningguta . Ai hoi i jergi bade isandume geli suwayan tui kūwaran i Batu tung ling de hese wasimbume ini kadalara cooha be gaifi $\underline{\mathrm{Sa} \mathrm{Bu} \mathrm{Su}}$ i bade isanjire sehe ..

$\underline{\text { Batu }}$ ere fonci ini bethei feye emgeri sain oho . hese be dahame dain de generengge tob seme \a Sa ci fakcame genere sain nashūn oho . damu ere jilacuka \a Sa gūnin i dolo ai gese gasara be we sara! Јa Sa Batu de tusure de mangga be safi uthai dele be baharakū

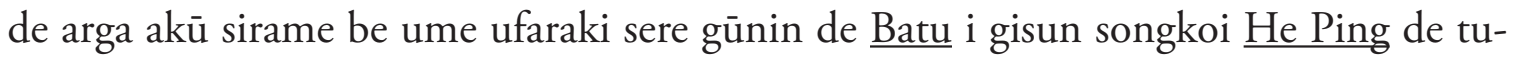
suhe .. Oros be dailara amba cooha Ya Ke Sa hecen be horime afame deribuhe. Ya Ke

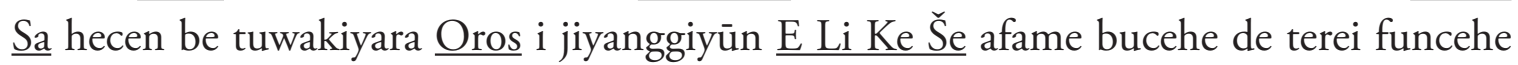
coohai meyen amba dulin samsime ukaha . ememungge dahame jihe ..

\section{Chinese}

第十四章: [布庫 $]^{16}$ 戰勝敵人，趁機查探母親下落

平春公在阿列克謝打敗俄羅斯後, 拆毀了阿列克謝的城牆, 並向俄羅斯 人頒令：「[你們] 不能再建造城牆」, 然後撤走軍隊, 回到璦琿。但在他們 離開後不久, 俄羅斯人在阿列克謝建造更堅固的城牆, 加強武裝。很多俄羅 斯的布衣人再次被招集, 如舊耕種和畜牧。此後, [俄羅斯人] 越過 [自己的 領土], 在索倫等地不斷大作搜掠。

康熙帝聞訊後十分憤怒, 故此頒令給寧古塔副都統薩布素, 調遣親兵, 遠征俄羅斯。薩布素駐守在關险以東, 他在盛京、寧古塔和璦琿等地招集眾 八旗兵力, 並頒令予護軍營的統領巴圖, 帶着其統率的軍隊, 集結在薩布素 所在之地。

16. 布庫是達斡爾族人。在與俄羅斯人作戰之前, 他的母親阿綸因為害怕自己成為阻繞布庫加入清軍的羈絆而 偷偷離開了兒子。 
最近巴圖的腿傷已經好了。他服從命令, 徑直前往戰區。[巴圖] 離開扎沙 的良機到了。但是, 這可憐的扎沙心裡想: 「唉, 誰明白我的抱怨呢? 」扎 沙明白到嫁給巴圖是困難的，然後想到沒法得到首選，自己不應錯過次選。 她遵從巴圖的說話，嫁給賀平 17 。

向俄羅斯開戰的大軍開始包圍和攻擊阿列克謝城。駐守阿列克謝的俄羅 斯將軍托爾布津戰死沙湯，其遺下的軍隊大半逃散，部份前來投降。

\section{English}

Chapter 14: $[\mathrm{Buku}]^{18}$ defeated the enemy and found an opportunity to make inquiries about his mother

After Duke Pingcun defeated Russia in Yaksa, he destroyed the city wall of Yaksa and issued a decree to the Russians: "[You] cannot build the city walls again." Then he withdrew his soldiers and returned to Aigun. But not long after they retreated, the Russians built the city walls stronger than before in Yaksa and strengthened their own forces. Again, many Russian commoners were gathered, practicing farming and herding as before. Hereafter [the Russians] went beyond [their own territory], and there was more plundering in Solon and other regions.

The Kangxi emperor heard of this and became very angry. He then issued an edict to the Ningguta lieutenant general Sabsu, dispatched crack troops, and sent a punitive expedition against the Russians. Sabsu took his own turn at duty in the east of the pass. He gathered together troops from all routes of the Eight Banners in Mukden, Ningguta, Aigu, as well as other places, and also issued orders to Batu, the commander of the imperial guards brigade. He [Batu] took his soldiers under his command and went to assemble at the place where Sabsu was located.

Recently, Batu had already recovered from his own leg wound. He followed [Sabsu's] order and went toward the war theater. This presented a good opportunity [for Batu] to leave Jasa. But the pitiful Jasa thought: "Ay, who understand my grief?" Jasa knew that it would be difficult to marry Batu, and then thinking that since there was no way to gain the top [option] she should not miss the next [best option], she followed Batu's words and married He Ping.

The imperial troops that waged war against Russia surrounded and launched an offensive on Yaksa city. When Aleksei [Tolbuzin], the Russian general guarding Yaksa city, died in battle, the majority of the remaining ranks dispersed and fled, [and] some came to surrender.

17. He Ping.

18. Buku belonged to the Dagur tribe. His mother A Lun had left him without any trace as she thought her presence might deter him from joining the Qing army against the Russian enemy. 
Commentary

Although my native language is Chinese, I have learned Manchu through the medium of English. I have thus translated the original text from Manchu into English first, and then finished the Chinese translation based on both the Manchu text and the English translated version. Compared to Manchu-English translation, translating a Manchu text into Chinese does not require considering the grammatical rules that are absent in the Chinese language. Chinese verbs, for example, are not conjugated, and it is often unnecessary to indicate whether a noun is singular or plural in Chinese translation.

Some issues regarding the Manchu-Chinese translation, however, merit some explanation. First, similar to classical Chinese texts, the subject of a sentence is sometimes omitted in the Manchu text of A Dagur Story, its author probably assuming that the reader would be able to guess the subject from the sequence of events. In order to clarify the meaning of the translated texts and to make them grammatically acceptable, I follow the plot and insert in brackets the subjects omitted in the Manchu text. For example, at the end of the first paragraph, "the Russians" and Eluosiren 俄羅斯人 are inserted in brackets in the English and Chinese translations respectively. Second, on some occasions I choose to use few Chinese words to represent comparatively long Manchu phrases for a more precise or lively expression. For example, I sometimes translate two Manchu verbs by using one Chinese term that denotes more than one action. For example, I translate samsime ukaha (“dispersed and fled") into taosan 逃散.

As Manchu, Chinese, and English belong to different language families, some issues arise from translating the Manchu text into both English and Chinese. To strike a balance between keeping the Manchu text's original meaning and following the Chinese and English grammatical rules, I sometimes change the part of speech of some Manchu words when translating the Manchu text into Chinese but do not do so in the Manchu-English translation. For example, in the last sentence of the first paragraph, while I translate tabcilarangge elei fulu oho into "there was more plundering" in English, I translate the phrase into buduan dasi soulüe 不斷大作搜掠 in Chinese, turning the noun tabcilarangge (plundering) into a verb. Moreover, to make the Chinese and English translated texts more fluent, I occasionally adjust the position of an adverb within a sentence. For example, in the first sentence of the second paragraph, I place the adverbial phrase ere fonci (recently or zuijin 最近) before the subject of the sentence, i.e., Batu 巴圖.

Another matter concerning the trilingual translation is that the English and Chinese translated texts are not strictly identical in meaning because English and Chinese grammars are different in many ways. In a number of cases, the Manchu-Chinese translation can be quite literal partly because $A$ Dagur Story was originally written in Chinese. In these cases, however, I reconstruct the whole sentence when translating the story into 
English in order to adhere to English grammar and to better convey its meaning to native English readers. For example, in the first line of the third paragraph, ini bethei feye emgeri sain oho can be translated fairly literally into Chinese, i.e., Ta de tuishang yijing hao le 他的腿傷已經好了. In English, however, as it is grammatically problematic to literally translate the Manchu sentence into, "His leg wound had already been recovered," the sentence has to be restructured and becomes, "He had already recovered from his own leg wound." 